\title{
Reframing Narratives in Yan Fu's Translation of Evolution and Ethics
}

\author{
$\mathrm{Ke} \mathrm{Li}$ \\ School of Foreign Languages \\ Wuhan Business University \\ Wuhan, China
}

\begin{abstract}
Along with the new tendency to apply the notion of narrative to all activities and disciplines, narrative theory, put forward by Mona Baker, provides us alternative understandings on Yan Fu's translation of Evolution and Ethics in Late Qing Dynasty. The purpose of this paper is to clarify how Yan Fu reframes narratives in his translation of Evolution and Ethics, tactically working his own patriotic ontological narrative into the conceptual narrative of Thomas HuxIey's biological work and effortlessly contributing himself to the construction of a public narrative of saving Chinese people from extinction and striving for progress, with China embedded into a meta-narrative of modernity.
\end{abstract}

Keywords-reframing narratives; Yan Fu; Evolution and Ethics; Mona Baker

\section{INTRODUCTION}

After the 1840 Opium War in the Late Qing Dynasty, China was reduced to a semi-feudal and semi-colonial society, greatly declining in politics, economy and culture. It was from then that China began its humiliating history of being bullied by the western powers. Consequently, a large number of insightful intellectuals engaged themselves in learning from the West by translating Western works, for the purpose of saving the motherland from perishing as well as to promote social innovation and progress. Known for his productive translations, $\mathrm{Yan} \mathrm{Fu}$ is undoubtedly the most influential figure at that time. His translated works included eight western monographs, written by Thomas Henry Huxley, Adam Smith, Herbert Spencer, John Stuart Mill, Jenks, W. S. Jevons and Baron de Montesquieu respectively, covering a wide range of politics, economy, sociology etc.

Yan $\mathrm{Fu}$ also enjoys a high reputation for setting the classic three-character principle of translation "xin, da, ya" in the preface of Tian Yan Lun, translation of British biologist Thomas Huxley's work Evolution and Ethics. For this reason, Yan Fu's translations have exerted great influence on China's intellectual world, social development as well as later translation studies. And in the meantime the popularity of Tian Yan Lun made it into a book of invaluable worth for research.

\section{REFRAMING STRATEGY OF NARRATIVE THEORY}

Mona Baker, a prestigious scholar of translation studies, put forth her narrative theory in her 2006 monograph Translation and Conflict: A Narrative Account. Baker's theory relies mainly on the concept of narrative as understood in social and communication theory, rather than narratology or linguistics. And here narratives could be comprehended as stories and serve as the only means of people getting to know the world. Baker applies this theory to "explore various ways in which translators and interpreters accentuate, undermine or modify contested aspects of the narratives encoded in the source text or utterance." (Mona Baker, 2007)

According to Baker, translators, rather than mere passive receivers of information, actively elaborate particular narratives. Thus she introduces a broad concept of "framing" to discuss how features of narratives work to produce an alternate narrative in the target context. She defines "(re)framing" as "an active strategy that implies agency and by means of which we consciously participate in the construction of reality" (Baker 2006:106). Then Baker exemplifies four major sub-strategies of (re)framing: temporal and spatial framing; selective appropriation of textual material; framing by labeling; repositioning of participants

\section{REFRAMING TRANSLATION IN TIAN YAN LUN}

Among Yan Fu's translated works, Tian Yan Lun, translation of Evolution and Ethics, was the earliest and also regarded as the most influential one. Yan $\mathrm{Fu}$, through his translation, relates the evolution rule in natural world with the prospects of human society. In China's case, its implication means importing advanced weapons and mechanical equipment, carrying on reform on social system, and educating the average citizens. He did his utmost, through his translation, to advocate science and encourage the Chinese people to learn science. What follows is how Yan Fu employs framing strategy to mediate the narratives in the source text.

\section{A. Temporal and Spatial Framing}

As is known to all, Thomas Huxley's Evolution and Ethics is an exclusively biological research product. After 
being translated by $\mathrm{Yan} \mathrm{Fu}$, its conceptual narrative has been widened to be embedded in a totally different public narrative in Chinese society.

Here is an example of temporal and spatial framing, explicitly clarifying how Yan Fu actively established a link between Huxley's disciplinary narrative and China's current narrative in a time of national crisis.

资生之物所加多者有限, 有术者既多取之而丰, 无具者自

少取焉而普; 丰者近昌, 普者邻灭。此洞识知微之士, 所为

惊心动魄, 于保群进化之图, 而知徒高睨大谈于夷夏轩轻之

间者，为深无益于事实也。(导言三趋异)

The words above, taken from Yan Fu's notes following the third passage, elaborate on how struggle for existence come into effect by revealing three tendencies of the natural process of evolution: firstly, the tendency of variation, then the tendency of favoring the most adapted variation, and lastly the tendency of exercising natural selection. This precisely echoes to Yan Fu's extremely condensed expression wuyi(无异), wuze (无择), wuzheng (无争). Although in this passage Huxley confines his talks within the scope of nature (i.e. all plants and animals), Yan $\mathrm{Fu}$, in his notes, further exemplifies Huxley's theory through discussion of human multiplication, thus also making humankind subject to Huxley's evolution theory. Then Yan $\mathrm{Fu}$ makes his appeal for saving Chinese people from extinction and striving for progress.

As we know, Yan Fu's interest was not Darwin's contributions to biology, but how could these exclusively scientific theories be applied into human society. The focus of Huxley was how to solve the living dilemma human face in the fierce competition of cosmic evolution, how to strengthen national sense of affinity, and how to combat all kinds of negative effects produced by cosmic evolution. According to Huxley, men's will could combat with cosmic and the future is optimistic. All of these are in accordance with Yan Yu's intentions, which were how to achieve survival and self-reliance. While on this point of how to exert human's will in front of natural selection, Darwin's choice was not to mention it, while Spencer hold that human beings should leave the heaven to take its own course, which Yan Yu thought would legalize and encourage western powers' aggressions.

\section{B. Selective Appropriation of Textual Material}

On the translation of Evolution and Ethic, Yan Fu did not translate all the content. Through omission and addition, Yan $\mathrm{Fu}$ undermined some particular aspects of Huxley's conceptual narrative. Here is an example of addition in his note:

In the fourth passage of Prolegomena in Tian Yan Lun, there is a long comment by $\mathrm{Yan} \mathrm{Fu}$, in which he feels obliged to offer explanations about topic of this passage.

本篇有云: 物不假人力而自生, 便为其地最宜之种。此 说固也。然不知分别观之则误人, 是不可以不论也。（严 复，2009:13)

Through this comment, Yan expressed his disapproval of Huxley's view that the fittest should be among ones having existed in a place before and he carefully explained through examples ranging from animals to plants and finally to human beings. He finally concluded that the fittest should not necessarily be among those having existed before, but those coming from other places.

When translating the fourth passage, Yan Fu clearly expressed his disagreement and had to add a comment to explain and clarify. In the comment, he gave the proofs from the animals in the America and Europe to the plants in China, from the animals and plants to human beings in the world and finally from people abroad to the Chinese people.

至如植物，则中国之蕃薯蓣来自吕宋，黄占来自占城， 蒲桃、苩宿来自西域, 薏茨载自日南, 此见诸史传者也。 夫无有迁地而良知此, 谁谓必本土固有者而后称最宜哉? 物竞既兴，负者日耗，区区人满，乌足特也哉！乌足特也哉! (Ibid:14)

Yan's reason for adding this comment was to prove that the native species are not always the fittest and this phenomenon was temporary, but permanent. In the last sentence, he reminded his Chinese readers not to be proud and take its large population for granted.

In fact, the officials and the average citizens hold a shared narrative for a long time that the Qing was a dominant power in the world boasting of its large population, resources, lands and goods, and that the Qing was naturally superior to other nations. The Chinese people believed that since they had been living on the land for thousands of years, they were the fittest, and did not have to worry about competition. It was the wrong concept that was strongly opposed by $\mathrm{Yan} \mathrm{Fu}$. Under these desperate circumstances, Yan Fu expressed his proposition that only through strengthening themselves could their nation and people be the fittest.

\section{Framing by Labeling}

The act of labeling involves how to address a person, place, group, event or any other key elements in a narrative. As a scientific work, Thomas Huxley's Evolution and Ethics inevitably is loaded with many technical terms incomprehensible to the natives, not to mention their equivalents in targeted context. Naturally, Yan Fu undertook the task of coining new expressions to refer to the new concepts, through which (re)framing strategy is employed. A typical example of the designation is what Yan recalled, in his preface, the translation of "Prolegomena". Yan Fu thoughtfully made several changes, from "zhiyan(危言)', “xuantan(悬谈)”, to the final version “daoyan(导言)”, repeatedly weighing each choice's implication. Similar dealings could be found in such cases as rendering "nerve" into "niefu(涅伏)", “logic” into “mingxue(名学)", “political nature” into "qunxing(群性)”, “man's place in nature” into “huazhongrenweilun( 化中人位论)”, “pure reason” into “qingjingzhili(清净之理)”. Those names are overtly culturallyridden and ideologically-charged within Chinese narrative.

The intention of Yan Fu's framing tendency is revealed more explicitly in his Preface to Tian Yan Lun:

后二百年, 有斯宾塞尔者, 以天演自然言化, 著书造

论, 贯天地人而一理之, 此亦晚近之绝作也。其为天演界说 
日: “翕以合质，辟以出力，始简易而终杂糅。”而《易》 则日：“坤，其静也兪，其动也辟。”至于全力不增减之 说, 则有自强不息为之先, 凡动必复之说, 则有消息之义居 其始。而“易不可见，乾坤或几乎息”之旨，尤为 “热力平 均, 天地乃毁”之言相发明也。此岂可悉谓之偶合也耶! 虽 然, 由斯之说, 必谓彼之所明, 皆吾中土所前者, 甚者可谓 其学皆得于东来, 则又不关事实, 适用自蔽之说也。

(Ibid:4)

These sayings suggest what Yan Fu has learnt from the West echoes to the thoughts long proposed in classic Chinese texts. For example, the saying of "The superior man, in accordance with this, nerves himself to ceaseless activity." is earlier than "law of conservation of energy" ( 全力不增 减）, and “third law of Newton”（凡动必复）is also later than Chinese law of describing changing status. In a word, it is evident that from Yan Fu's point of view Chinese learning has priority over the Western learning.

\section{Repositioning of Participants}

Much repositioning in translation is realized within the text.

Firstly, Yan Fu' use of Tongcheng classic Chinese style succeeds in reframing Huxley's disciplinary scientific work Evolution and Ethics into a beautifully rendered translated text.

Lun Xun, a most renowned progressive writer in modem China, once recollected his impression on Tian Yan Lun, style in particular, with a humorous touch.

\footnotetext{
“最好懂的自然是《天演论》, 桐城气息十足, 连字的平都留 心。摇头晃脑的读起来, 真是音调锃铭, 使人不自觉其头晕。……他 [严复] 为什么要千这一手把戏呢? 答案是: 那时的留学生没有现在这 么阔气, 社会上大抵以为西洋人只会做机器——尤其是自鸣钟——留 学生只会讲鬼子话, 所以算不了 ' \pm ' 人的。因为他便来锃铭一下 子, 铣铭得吴汝纶也肯给他作序, 这一序, 别的生意也就源源而来 了。”（鲁迅 2006:193）
}

It can be easily seen that Lu Xun found Yan Fu's choice of Tongcheng style quite agreeable, as in his vivid description, "I couldn't help refraining from being intoxicated while chanting Yan Fu's amazing prose (Tian Yan Lun) full of cadences." And then $\mathrm{Lu}$ Xun gave a reasonable answer to Yan Fu's choice of Tongcheng style. Even Yan Fu, being one of the students with oversea experiences, didn't rank among Shi class (the educated of nobility). What's more, it had long been held that Westerners were only skilled at machinery, thus students like Yan Fu were not expected to excel in classical Chinese writing. Since now Yan $\mathrm{Fu}$ had succeeded in challenging the impartial idea by rendering Evolution and Ethics into classical Chinese with great craftsmanship, he must be awaited for ample favorable opportunities in the future.

According to Yan Fu own expectation, addressees of Tian Yan Lun belonged to the intelligentsia. Generally speaking, the expected readership of Tian Yan Lun was mainly composed of three types: the conservative literati who represented not only the dominant ideology of China in that period, but also the dominant political force at court(that is, they were also the dominant force of the ruling class), those feudal reformers enthused in foreign affairs, who represented another, though not the dominant, political force of the ruling class, and the progressive intellectuals such as constitutional reformists.

The warm welcome of Yan Fu's Tian Yan Lun, especially from scholar officials, responds well to Lu Xun's insightful view. Yan Fu's intentional modification of textual feature, which is clearly favored within the public narrative of scholar officials, narrows the gap between him and the elite intellectuals, fulfilling a function of repositioning himself as one of his targeted community.

Secondly, repositioning in translation could also be achieved through other linguistic devices. Here is an example:

\section{- Original}

It may be safely assumed that, two thousand years ago, before Caesar set foot in southern Britain, the whole country-side visible from the windows of the room in which I write, was in what is called, * the state of Nature.55 Except, it may be? by raising a few sepulchral mounds, such as those which still, here and there, break the following contours of the downs, man9s hands had made no mark upon it; and the thin veil of vegetation which overspread the broad-backed heights and the shelving sides of the combs was unaffected by his industry.(Huxley, 2009:1)

- Translation

赫胥黎独处一室之中, 在英伦之南, 背山而面野。㨫外诸 境, 历历如在几下。乃悬想二千年前, 当罗马大将恺彻未到 时, 此间有何景物。计惟有天造草味, 人功未施, 其借征人 境者, 不过几处荒坟，散件陂陀起伏间。而灌木丛林，龙茸 山麓, 未经删治如今日者, 则无疑也。（严复 2009:1 导言一 察变)

There is an obvious shift in pronoun use in the beginning paragraph of Evolution and Ethics, also, the most quoted one for analysis. The first person "I" in the original text is replaced with the third person “赫胥黎”, in the target text. This sublte change turned an objective academic account into something of a novel, a flourishing genre in the Late Qing Dynasty. As is known to all, narrating a story from the third person point of view has been a classic mode since the being of novels. The popularity of novels could be inferred from Wu Rulun's words in the preface of Tian Yan Lun,

“吾则以谓今西书之流入吾国, 适当吾文学靡判之时, 士大夫相 務尚以为学者, 时文耳, 公牍耳, 说部耳。舍此三者, 儿无所为书。 而是三者, 固不足与文学之事。今西书虽多新学, 顾吾之上以其时 文、公牍、说部之词, 译而传之, 有识者方鄙夷而不知顾。民智之沼 何由? ” (Ibid: 2)

Nevertheless Wu stated a fact in his preface to Tian Yan Lun that elite intellectuals have a low opinion of novels despite their popularity among the common people. Although it has been discussed that Yan Fu's Tongcheng style quite appealed to Shi class, this pronoun shift suggests that in Yan Fu's mind the preference of literature of common people shouldn't be ignored either. Admittedly, such reframing move could arouse citizen's interests to read, 
enhancing the interplay between ontological and public narratives of the common.

\section{CONCLUSION}

Yan Fu's translation of Evolution and Ethics changed the constitutions of Chinese culture and brought new words into China, which greatly stimulated people's enthusiasm to learn. Owing to the important role Tian Yan Lun plays in the Chinese history, it needs specific academic attention. With the help of Mona Baker's narrative theory, this paper presents how Yan Fu worked his own patriotic ontological narrative into the conceptual narrative of Thomas Huxley's biological work Evolution and Ethics, and effortlessly contributed himself to the construction of a public narrative of saving Chinese people from extinction and striving for progress, with China embedded into a meta-narrative of modernity.

Admittedly, the paper still needs much improvement through further studies. Firstly, it may seem not adequate to list two major public narratives Yan Fu tried to contest and challenge, as there must had been certain positive public narrative, promoted by other patriotic intellectuals, Yan Fu would like to subscribe to; Secondly, it somewhat lacks enough accounts on meta-narrative of modernity considering the fact that expounding on a meta-narrative, which has to be discussed beyond the border of one country, demands much more materials and labor. Moreover, it is worthwhile to give a careful thought on questions concerning narratives like: Why did others in Yan Fu's times, with basically the same ontological narrative, failed to promote it? Why other translated texts of Thomas Huxley's Evolution and Ethics, the same conceptual narrative, could not gain success like Yan Fu's Tian Yan Lun?

\section{ACKNOWLEDGMENT}

Research for this article was supported by Center for Research on Sino-Western Language and Culture, School of Foreign Languages, Wuhan Business University.

\section{REFERENCES}

[1] Baker, Mona. Narrative in and of Translation [J]. SKASE Journal of Translation and Interpretation. 2005,1.pp. 4-13.

[2] Baker, Mona. Translation and Conflict: A Narrative Account [M]. London and New York: Routledge. 2006

[3] Baker, Mona. Translation and Activism: Emerging Patterns of Narrative Community [J].The Massachusetts Review. 2006,3.pp. 5278.

[4] Baker, Mona. Reframing Conflict in Translation [J]. Social Semiotics. 2007,.1.pp. 152-169.

[5] Yan Fu. Tian Yan Lun [M]. China Youth Publishing Group, 2009.

[6] Yan Fu. collected works of Yan Fu [M]. Beijing: Zhonghua Book Company, 1986.

[7] Shen Suru. On faithfulness, expressiveness and elegance: On Yan Fu's Translation Theory [M].Beijing: The Commercial Press, 1998.

[8] Wang Kefei. The Assimilation of Modern Western Political Science Thought in China and Japan: Yan Fu and Japanese Enlightenment Scholars [M]. Beijing: China social sciences press, 1996. 